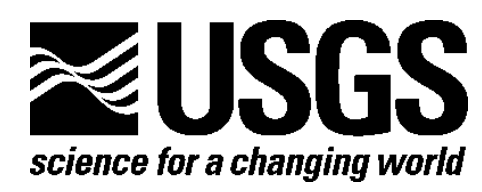

\title{
Geochemical Data for Colorado Soils: Results from the 2006 State-Scale Geochemical Survey
}

By David B. Smith, Karl J. Ellefsen, and James E. Kilburn

Data Series 520

U.S. Department of the Interior

U.S. Geological Survey 


\section{U.S. Department of the Interior \\ KEN SALAZAR, Secretary}

\section{U.S. Geological Survey Marcia K. McNutt, Director}

U.S. Geological Survey, Reston, Virginia 2010

For product and ordering information:

World Wide Web: http://www.usgs.gov/pubprod

Telephone: 1-888-ASK-USGS

For more information on the USGS-the Federal source for science about the Earth, its natural and living resources, natural hazards, and the environment: World Wide Web: http://www.usgs.gov

Telephone: 1-888-ASK-USGS

Suggested citation:

Smith, D.B., Ellefsen, K.J., and Kilburn, J.E., 2010, Geochemical data for Colorado soilsResults from the 2006 state-scale geochemical survey: U.S. Geological Survey, Data Series $520,9 \mathrm{p}$.

Any use of trade, product, or firm names is for descriptive purposes only and does not imply endorsement by the U.S. Government.

Although this report is in the public domain, permission must be secured from the individual copyright owners to reproduce any copyrighted material contained within this report. 


\section{Contents}

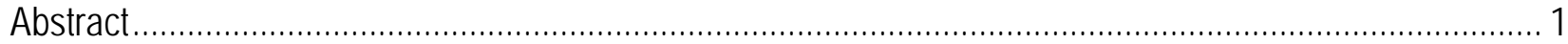

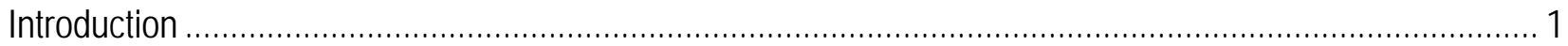

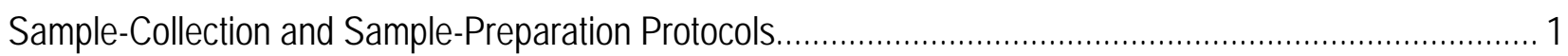

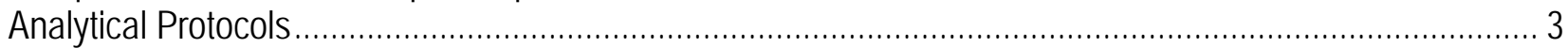

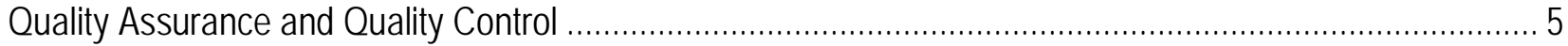

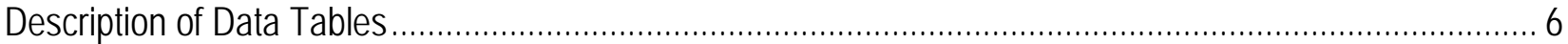

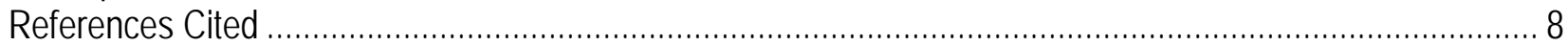

\section{Figure}

1. Map of Colorado showing the locations of 960 soil samples collected for chemical analysis. ................2

\section{Tables}

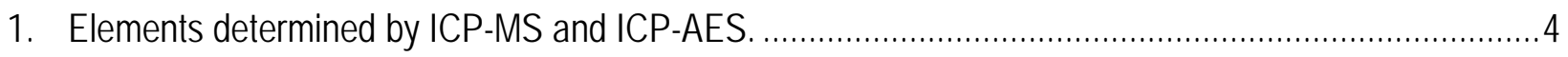

2. Statistical summary for geochemical data on 0 - to $15-\mathrm{cm}$ soils from Colorado.................................... 7

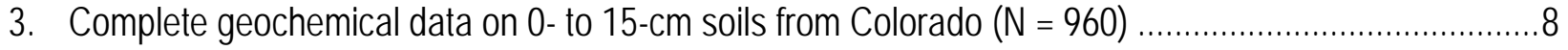




\section{Conversion Factors}

\begin{tabular}{lcl}
\multicolumn{1}{c}{ SI to Inch/Pound } & \multicolumn{1}{c}{ By } & To obtain \\
\hline & Length & \\
\hline centimeter (cm) & 0.3937 & inch (in) \\
millimeter (mm) & 0.03937 & inch (in) \\
meter (m) & 3.281 & foot (ft) \\
kilometer $(\mathrm{km})$ & 0.6214 & mile (mi) \\
\hline & Area & \\
\hline square kilometer $\left(\mathrm{km}^{2}\right)$ & 247.1 & acre \\
\hline & Mass & \\
\hline gram (g) & 0.03527 & ounce, avoirdupois (oz) \\
kilogram $(\mathrm{kg})$ & 2.205 & pound, avoirdupois (lb)
\end{tabular}

Temperature in degrees Celsius $\left({ }^{\circ} \mathrm{C}\right)$ may be converted to degrees Fahrenheit $\left({ }^{\circ} \mathrm{F}\right)$ as follows:

${ }^{\circ} \mathrm{F}=\left(1.8 \times{ }^{\circ} \mathrm{C}\right)+32$ 


\title{
Geochemical Data for Colorado Soils: Results from the 2006 State-Scale Geochemical Survey
}

\author{
By David B. Smith, Karl J. Ellefsen, and James E. Kilburn
}

\begin{abstract}
In 2006, soil samples were collected at 960 sites ( 1 site per 280 square kilometers) throughout the state of Colorado. These samples were collected from a depth of $0-15$ centimeters and, following a near-total multi-acid digestion, were analyzed for a suite of more than 40 major and trace elements. The resulting data set provides a baseline for the natural variation in soil geochemistry for Colorado and forms the basis for detecting changes in soil composition that might result from natural processes or anthropogenic activities. This report describes the sampling and analytical protocols used and makes available all the soil geochemical data generated in the study.
\end{abstract}

\section{Introduction}

Understanding the natural variation in the concentration of major and trace elements in soil-particularly potentially harmful elements such as lead, arsenic, mercury, and cadmium - is essential to a proper assessment of soil contamination caused by human activities. Such background data are necessary for environmental monitoring, remediation of contaminated sites, land-use planning, and ecological evaluations. Reliable, comprehensive information about background levels of elements in Colorado soils will facilitate scientifically defensible decisions by industries and policy makers.

In 2006, the U.S Geological Survey (USGS) carried out a soil-sampling program in the state of Colorado to establish a geochemical database containing the information described above. The purpose of this report is to provide information on the protocols for the sampling and chemical analysis of soils and to make available the soil geochemical data generated in the study.

\section{Sample-Collection and Sample-Preparation Protocols}

To select sites for soil sampling, the state of Colorado was first divided into 966 equal-area polygons. A target site was then selected at random from within each of the polygons. This represented a density of approximately 1 site per 280 square kilometers $\left(\mathrm{km}^{2}\right)$. The actual site from which a sample was collected was chosen within the polygon's most representative landscape as near as possible to the target site while also taking into consideration the following guidelines:

1. No sample should be collected from within 200 meters $(\mathrm{m})$ of a major highway.

2. No sample should be collected closer than $50 \mathrm{~m}$ to a rural road. 
3. No sample should be collected closer than $100 \mathrm{~m}$ to a building or structure.

Because of problems in gaining access to sample sites in 6 of the polygons, 960 sites were sampled during this study (fig. 1). This small reduction in the number of sites sampled had a negligible effect on the sample density.
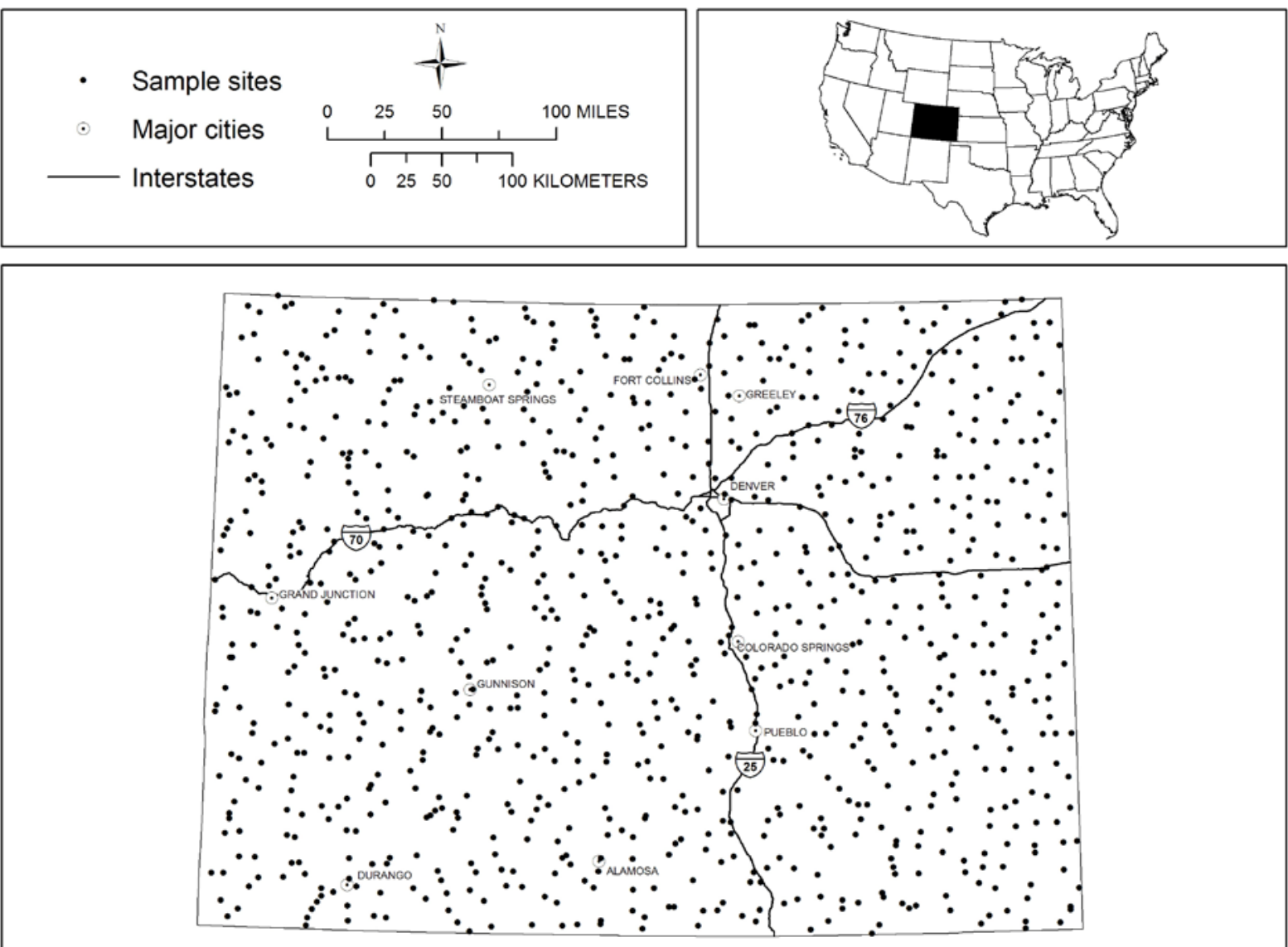

Figure 1. Map of Colorado showing the locations of 960 soil samples collected for chemical analysis.

At each site, a sample of soil was collected from a depth of 0 to 15 centimeters $(\mathrm{cm})$ after removing loose plant debris (if any) from the ground surface. This particular sample medium was selected to be consistent with published soil geochemical data sets for the Front Range Urban Corridor (Severson and Tourtelot, 1994) and the Denver metropolitan area (Kilburn and others, 2007). The samples were air dried at ambient temperature, disaggregated, and sieved through a 2-millimeter $(\mathrm{mm})$ stainless steel screen. Material less than $2 \mathrm{~mm}$ in size was crushed to less than 150 micrometers $(\mu \mathrm{m})$ in a ceramic mill and thoroughly mixed to ensure homogeneity. The crushed samples were randomized prior to chemical analysis to avoid confusing spatial variation with any possible systematic bias within a given analytical technique. This randomization does not eliminate a systematic error, but the error is effectively transformed into one that is random with respect to geographic location (Tidball, 1984). 


\section{Analytical Protocols}

The prepared samples were sent to a USGS contract geochemical laboratory for major and trace element analysis. The concentrations of the elements aluminum (Al), calcium $(\mathrm{Ca})$, iron $(\mathrm{Fe})$, potassium $(\mathrm{K})$, magnesium $(\mathrm{Mg})$, sodium $(\mathrm{Na})$, sulfur $(\mathrm{S})$, titanium (Ti), silver (Ag), arsenic (As), barium (Ba), beryllium (Be), bismuth (Bi), cadmium (Cd), cerium $(\mathrm{Ce})$, cobalt $(\mathrm{Co})$, chromium $(\mathrm{Cr})$, cesium $(\mathrm{Cs})$, copper $(\mathrm{Cu})$, gallium $(\mathrm{Ga})$, indium (In), lanthanum (La), lithium (Li), manganese $(\mathrm{Mn})$, molybdenum $(\mathrm{Mo})$, niobium $(\mathrm{Nb})$, nickel $(\mathrm{Ni})$, phosphorus $(\mathrm{P})$, lead $(\mathrm{Pb})$, rubidium $(\mathrm{Rb})$, antimony $(\mathrm{Sb})$, scandium $(\mathrm{Sc})$, tin $(\mathrm{Sn})$, strontium (Sr), tellurium (Te), thorium (Th), thallium $(\mathrm{Tl})$, uranium $(\mathrm{U})$, vanadium $(\mathrm{V})$, tungsten $(\mathrm{W})$, yttrium $(\mathrm{Y})$, and zinc $(\mathrm{Zn})$ were determined by inductively coupled plasma-atomic emission spectrometry (ICP-AES) by a method similar to Briggs (2002) and by inductively coupled plasma-mass spectrometry (ICP-MS) by a method similar to Briggs and Meier (2002). A soil sample of 0.25 grams (g) was digested using a mixture of concentrated hydrochloric, nitric, perchloric, and hydrofluoric acids at temperatures between 110 and $160^{\circ} \mathrm{C}$.

The four-acid digestion results in a nearly total dissolution of most mineral constituents in soil. However, it does not fully dissolve some of the more refractory or resistant minerals. Some examples of such incomplete dissolution include $\mathrm{Ba}$ in barite, $\mathrm{Cr}$ in chromite, $\mathrm{Ti}$ in rutile, $\mathrm{Sn}$ in cassiterite, $\mathrm{Al}$ in corundum, and rare earth elements in monazite (Briggs, 2002). An aliquot of the digested sample was aspirated into the ICP-AES and ICP-MS instruments and the concentrations of the optimal elements were determined. The ICP-AES method is best for the major elements, sulfur, and elements with relatively high concentrations not requiring a low detection limit, and the ICP-MS method is optimal for trace elements requiring lower limits of determination near or below their crustal abundance and for elements not determined by ICP-AES. The lower limits of determination (LLD) are listed in table 1. 
Table 1. Elements determined by ICP-MS and ICP-AES.

[LLD, lower limit of determination; ICP-MS, inductively coupled plasma-mass spectrometry; ICP-AES, inductively coupled plasma-atomic emission spectrometry]

\begin{tabular}{|c|c|c|}
\hline Element & Method & LLD \\
\hline Aluminum & ICP-AES & $0.01 \%$ \\
\hline Calcium & ICP-AES & $0.01 \%$ \\
\hline Iron & ICP-AES & $0.01 \%$ \\
\hline Potassium & ICP-AES & $0.01 \%$ \\
\hline Magnesium & ICP-AES & $0.01 \%$ \\
\hline Sodium & ICP-AES & $0.01 \%$ \\
\hline Phosphorous & ICP-AES & $50 \mathrm{mg} / \mathrm{kg}$ \\
\hline Titanium & ICP-AES & $0.01 \%$ \\
\hline Silver & ICP-MS & $1 \mathrm{mg} / \mathrm{kg}$ \\
\hline Arsenic & ICP-MS & $1 \mathrm{mg} / \mathrm{kg}$ \\
\hline Barium & ICP-MS & $5 \mathrm{mg} / \mathrm{kg}$ \\
\hline Beryllium & ICP-MS & $0.1 \mathrm{mg} / \mathrm{kg}$ \\
\hline Bismuth & ICP-MS & $0.04 \mathrm{mg} / \mathrm{kg}$ \\
\hline Cadmium & ICP-MS & $0.1 \mathrm{mg} / \mathrm{kg}$ \\
\hline Cerium & ICP-MS & $0.05 \mathrm{mg} / \mathrm{kg}$ \\
\hline Cobalt & ICP-MS & $0.1 \mathrm{mg} / \mathrm{kg}$ \\
\hline Chromium & ICP-MS & $1 \mathrm{mg} / \mathrm{kg}$ \\
\hline Cesium & ICP-MS & $0.05 \mathrm{mg} / \mathrm{kg}$ \\
\hline Copper & ICP-MS & $0.5 \mathrm{mg} / \mathrm{kg}$ \\
\hline Gallium & ICP-MS & $0.05 \mathrm{mg} / \mathrm{kg}$ \\
\hline Indium & ICP-MS & $0.02 \mathrm{mg} / \mathrm{kg}$ \\
\hline Lanthanum & ICP-MS & $0.5 \mathrm{mg} / \mathrm{kg}$ \\
\hline Lithium & ICP-MS & $1 \mathrm{mg} / \mathrm{kg}$ \\
\hline Manganese & ICP-MS & $5 \mathrm{mg} / \mathrm{kg}$ \\
\hline Molybdenum & ICP-MS & $0.05 \mathrm{mg} / \mathrm{kg}$ \\
\hline Niobium & ICP-MS & $0.1 \mathrm{mg} / \mathrm{kg}$ \\
\hline Nickel & ICP-MS & $0.5 \mathrm{mg} / \mathrm{kg}$ \\
\hline Lead & ICP-MS & $0.5 \mathrm{mg} / \mathrm{kg}$ \\
\hline Rubidium & ICP-MS & $0.2 \mathrm{mg} / \mathrm{kg}$ \\
\hline Sulfur & ICP-MS & $0.01 \%$ \\
\hline Antimony & ICP-MS & $0.05 \mathrm{mg} / \mathrm{kg}$ \\
\hline Scandium & ICP-MS & $0.1 \mathrm{mg} / \mathrm{kg}$ \\
\hline Tin & ICP-MS & $0.1 \mathrm{mg} / \mathrm{kg}$ \\
\hline Strontium & ICP-MS & $0.5 \mathrm{mg} / \mathrm{kg}$ \\
\hline Tellurium & ICP-MS & $0.1 \mathrm{mg} / \mathrm{kg}$ \\
\hline Thallium & ICP-MS & $0.1 \mathrm{mg} / \mathrm{kg}$ \\
\hline Thorium & ICP-MS & $0.2 \mathrm{mg} / \mathrm{kg}$ \\
\hline Uranium & ICP-MS & $0.1 \mathrm{mg} / \mathrm{kg}$ \\
\hline Vanadium & ICP-MS & $1 \mathrm{mg} / \mathrm{kg}$ \\
\hline Tungsten & ICP-MS & $0.1 \mathrm{mg} / \mathrm{kg}$ \\
\hline Yttrium & ICP-MS & $0.1 \mathrm{mg} / \mathrm{kg}$ \\
\hline Zinc & ICP-MS & $1 \mathrm{mg} / \mathrm{kg}$ \\
\hline
\end{tabular}


The concentration of $\mathrm{Hg}$ was determined by treating $0.1 \mathrm{~g}$ of sample with a mixture of nitric and hydrochloric acids and heating for 30 minutes (min). Once cooled, solutions of sulfuric acid, potassium permanganate, and potassium persulfate were added, followed by sodium chloride-hydroxylamine sulfate. The final solution was reduced by stannous chloride and analyzed by atomic absorption spectrometry. This method is a modification of that published by the U.S. Environmental Protection Agency (2007). The LLD is 0.02 milligrams per kilogram $(\mathrm{mg} / \mathrm{kg})$.

The concentration of Selenium (Se) was determined by digesting $0.25 \mathrm{~g}$ of sample using a multi-acid procedure. At the end of the digestion period, Se was reduced to the +4 oxidation state. Sodium borohydride was then added to form the gaseous Se hydride, which was then transported with inert gas to an atomic absorption spectrometer. The method is similar to that published by Hageman and Brown (2002). The LLD is $0.2 \mathrm{mg} / \mathrm{kg}$.

\section{Quality Assurance and Quality Control}

Quality assurance (QA) is mainly the concern of the analytical laboratory. The various components of the QA plan include standard operating procedures, instrument logs, training records, data acceptance and rejection criteria, and laboratory audits. Unlike the unquantifiable QA element, the quality control (QC) element measures the bias and precision of the data produced by a specific analytical method. The bias and precision are established through the analysis of reference materials (RMs) and sample replicates, respectively.

The samples that passed through the analytical process in the USGS laboratories received QC checks on two separate levels. The first level involved QC assessment by the USGS contract laboratory. In the next level, quality was assessed by the USGS QC officer.

The USGS contract laboratory is accredited to the International Organization for Standardization/International Electrotechnical Commission 17025 standard, which includes both QA and QC protocols. The QC is monitored by analyzing an RM with every batch of 48 samples. The RM most often used is a syenite rock standard (SY-3) developed by the Canadian Centre for Mineral and Energy Technology (Govindaraju, 1989). Shewhart Control Charts (Taylor, 1987) are generated for the RM analyses and reviewed with every report as part of the internal quality audits.

The accuracy for elements determined by ICP-MS and ICP-AES was considered acceptable if recovery was within the range of 85-115 percent at five times the LLD. The accuracy for $\mathrm{Hg}$ and Se was considered acceptable if recovery was within 80-120 percent at five times the LLD.

At the second tier, the USGS QC officer assessed precision and accuracy on the basis of five RMs that were inserted between every batch of 50 samples. The soil RMs used in this study were SRM 2709 and SoNE-1. SRM 2709, a soil from the San Joaquin Valley of central California, is a certified RM available from the National Institute of Standards and Technology and is used to assess both bias and precision (National Institute of Standards and Technology, 2003). The acceptance criteria for accuracy are the same as those itemized earlier as used by the contract laboratory.

SoNE-1 is a USGS in-house, non-certified soil RM prepared specifically for the North American Soil Geochemical Landscapes Project (Smith and others, 2009). It was collected from the Sharpsburg Soil Series (Natural Resources Conservation Service, 2008) in Lancaster County, Nebr., and is used in this study to assess only precision. The precision 
for elements determined by ICP-MS and ICP-AES was considered acceptable if the calculated relative standard deviation (RSD) of duplicate samples is no greater than 15 percent. The precision for $\mathrm{Hg}$ and Se was considered acceptable if the calculated RSD of duplicate samples was no greater than 20 percent.

\section{Description of Data Tables}

Table 2 shows a statistical summary of the major and trace element data generated from the Colorado soil samples. Table 3 presents the complete analytical results for the Colorado soils. 
Table 2. Statistical summary for geochemical data on $0-15-\mathrm{cm}$ soils from Colorado.

$[\mathrm{N}=960$; LLD, lower limit of determination; Min, minimum; Q1, first quartile; Q3, third quartile; Max, maximum; MAD, median absolute deviation; $\mathrm{mg} / \mathrm{kg}$, milligrams per kilogram]

\begin{tabular}{|c|c|c|c|c|c|c|c|c|}
\hline Element & $\begin{array}{c}\text { Concentration } \\
\text { units }\end{array}$ & $\begin{array}{c}\text { Number of } \\
\text { samples } \\
\text { below LLD }\end{array}$ & Min & Q1 & Median & Q3 & $\operatorname{Max}$ & MAD \\
\hline Aluminum & $\%$ & 0 & 1.12 & 4.66 & 5.54 & 6.35 & 9.98 & 1.26 \\
\hline Calcium & $\%$ & 0 & 0.11 & 0.71 & 1.23 & 2.38 & 21.9 & 0.98 \\
\hline Iron & $\%$ & 0 & 0.27 & 1.55 & 2.14 & 2.77 & 9.42 & 0.90 \\
\hline Potassium & $\%$ & 0 & 0.38 & 1.93 & 2.29 & 2.65 & 5.86 & 0.53 \\
\hline Magnesium & $\%$ & 0 & 0.03 & 0.37 & 0.57 & 0.79 & 3.77 & 0.31 \\
\hline Sodium & $\%$ & 0 & 0.07 & 0.69 & 0.90 & 1.29 & 4.05 & 0.41 \\
\hline Sulfur & $\%$ & 29 & $<0.01$ & 0.02 & 0.03 & 0.04 & 9.54 & 0.015 \\
\hline Titanium & $\%$ & 0 & 0.03 & 0.15 & 0.20 & 0.25 & 1.21 & 0.074 \\
\hline Arsenic & $\mathrm{mg} / \mathrm{kg}$ & 4 & $<1$ & 3 & 5 & 7 & 126 & 3.0 \\
\hline Silver & $\mathrm{mg} / \mathrm{kg}$ & 941 & $<1$ & $<1$ & $<1$ & $<1$ & 35 & 0 \\
\hline Barium & $\mathrm{mg} / \mathrm{kg}$ & 0 & 155 & 606 & 719 & 814 & 4,660 & 153 \\
\hline Beryllium & $\mathrm{mg} / \mathrm{kg}$ & 0 & 0.4 & 1.3 & 1.6 & 1.9 & 6.4 & 0.44 \\
\hline Bismuth & $\mathrm{mg} / \mathrm{kg}$ & 11 & $<0.04$ & 0.12 & 0.18 & 0.24 & 14.6 & 0.089 \\
\hline Cadmium & $\mathrm{mg} / \mathrm{kg}$ & 54 & $<0.1$ & 0.2 & 0.3 & 0.4 & 20.2 & 0.15 \\
\hline Cerium & $\mathrm{mg} / \mathrm{kg}$ & 0 & 14.6 & 52.3 & 63.9 & 76.7 & 350 & 17.9 \\
\hline Cobalt & $\mathrm{mg} / \mathrm{kg}$ & 0 & 0.7 & 5.2 & 7.3 & 9.4 & 43.3 & 3.1 \\
\hline Chromium & $\mathrm{mg} / \mathrm{kg}$ & 0 & 3 & 20 & 29 & 39 & 141 & 14.8 \\
\hline Cesium & $\mathrm{mg} / \mathrm{kg}$ & 735 & $<5$ & $<5$ & $<5$ & 5 & 22 & 0 \\
\hline Copper & $\mathrm{mg} / \mathrm{kg}$ & 0 & 1.7 & 10.7 & 15.6 & 20.8 & 464 & 7.6 \\
\hline Gallium & $\mathrm{mg} / \mathrm{kg}$ & 0 & 2.8 & 10.4 & 12.9 & 15.1 & 26.5 & 3.5 \\
\hline Mercury & $\mathrm{mg} / \mathrm{kg}$ & 662 & $<0.02$ & $<0.02$ & $<0.02$ & 0.02 & 0.4 & 0 \\
\hline Indium & $\mathrm{mg} / \mathrm{kg}$ & 135 & $<0.02$ & 0.03 & 0.04 & 0.05 & 13.8 & 0.015 \\
\hline Lanthanum & $\mathrm{mg} / \mathrm{kg}$ & 0 & 7.5 & 27.1 & 33.1 & 38.9 & 176 & 8.7 \\
\hline Lithium & $\mathrm{mg} / \mathrm{kg}$ & 0 & 4 & 16 & 21 & 28 & 259 & 8.9 \\
\hline Manganese & $\mathrm{mg} / \mathrm{kg}$ & 0 & 75 & 316 & 431 & 608 & 3,460 & 196 \\
\hline Molybdenum & $\mathrm{mg} / \mathrm{kg}$ & 0 & 0.15 & 0.64 & 0.97 & 1.44 & 23.4 & 0.56 \\
\hline Niobium & $\mathrm{mg} / \mathrm{kg}$ & 0 & 1.5 & 7.1 & 9.1 & 11.3 & 69.9 & 3.1 \\
\hline Nickel & $\mathrm{mg} / \mathrm{kg}$ & 0 & 2 & 9.3 & 13.8 & 19.1 & 149 & 7.3 \\
\hline Phosphorous & $\mathrm{mg} / \mathrm{kg}$ & 5 & $<50$ & 450 & 650 & 860 & 2,840 & 296 \\
\hline Lead & $\mathrm{mg} / \mathrm{kg}$ & 0 & 5.5 & 18.8 & 21.7 & 26.5 & 3,600 & 5.3 \\
\hline Rubidium & $\mathrm{mg} / \mathrm{kg}$ & 0 & 22.1 & 77.3 & 91.6 & 105 & 312 & 20.8 \\
\hline Antimony & $\mathrm{mg} / \mathrm{kg}$ & 2 & $<0.05$ & 0.34 & 0.5 & 0.72 & 66.7 & 0.27 \\
\hline Scandium & $\mathrm{mg} / \mathrm{kg}$ & 0 & 0.9 & 5 & 6.8 & 8.6 & 33.9 & 2.7 \\
\hline Selenium & $\mathrm{mg} / \mathrm{kg}$ & 435 & $<0.2$ & $<0.2$ & 0.2 & 0.4 & 11.3 & 0 \\
\hline Tin & $\mathrm{mg} / \mathrm{kg}$ & 0 & 0.2 & 1.1 & 1.4 & 1.7 & 125 & 0.44 \\
\hline Strontium & $\mathrm{mg} / \mathrm{kg}$ & 0 & 37.5 & 134 & 181 & 254 & 1,430 & 79 \\
\hline Tellurium & $\mathrm{mg} / \mathrm{kg}$ & 899 & $<0.1$ & $<0.1$ & $<0.1$ & $<0.1$ & 4.3 & 0 \\
\hline Thorium & $\mathrm{mg} / \mathrm{kg}$ & 0 & 2.2 & 8 & 10 & 12.6 & 82.6 & 3.4 \\
\hline Thallium & $\mathrm{mg} / \mathrm{kg}$ & 0 & 0.1 & 0.5 & 0.6 & 0.7 & 3.1 & 0.15 \\
\hline Uranium & $\mathrm{mg} / \mathrm{kg}$ & 0 & 0.6 & 1.9 & 2.4 & 3 & 18.6 & 0.74 \\
\hline Vanadium & $\mathrm{mg} / \mathrm{kg}$ & 0 & 4 & 40 & 59 & 80 & 373 & 29.6 \\
\hline Tungsten & $\mathrm{mg} / \mathrm{kg}$ & 0 & 0.2 & 0.6 & 0.8 & 1 & 14 & 0.3 \\
\hline Yttrium & $\mathrm{mg} / \mathrm{kg}$ & 0 & 3.8 & 12.8 & 16.2 & 19.3 & 169 & 4.8 \\
\hline Zinc & $\mathrm{mg} / \mathrm{kg}$ & 0 & 10 & 47 & 66 & 90 & 7,000 & 32.6 \\
\hline
\end{tabular}


To view Table 3 as an Excel file: CLICK HERE.

To view Table 3 as a PDF: CLICK HERE.

\section{References Cited}

Briggs, P.H., 2002, The determination of forty elements in geological and botanical samples by inductively coupled plasma-atomic emission spectrometry, chap. G of Taggart, J.E., Jr., ed., Analytical methods for chemical analysis of geologic and other materials, U.S. Geological Survey: U.S. Geological Survey Open-File Report 02-223, 18 p., accessed June 7, 2010, at http://pubs.usgs.gov/of/2002/ofr-02-0223/G01 fortyelementICPAESsolid_M.pdf.

Briggs, P.H., and Meier, A.L., 2002, The determination of forty-two elements in geological materials by inductively coupled plasma-mass spectrometry, chap. I of Taggart, J.E., Jr., ed., Analytical methods for chemical analysis of geologic and other materials, U.S. Geological Survey: U.S. Geological Survey Open-File Report 02-223, 14 p., accessed June 7, 2010, at http://pubs.usgs.gov/of/2002/ofr-02-0223/I20NAWQAPlus_M.pdf.

Govindaraju, Kuppusami, ed., 1989, Compilation of working values and sample description for 272 geostandards: Geostandards Newsletter, v. 13, special issue, 114 p.

Hageman. P.L., and Brown, Z.A., 2002, Arsenic and selenium by flow injection or continuous flow-hydride generation-atomic absorption spectrometry, chap. L of Taggart, J.E., Jr., ed., Analytical methods for chemical analysis of geologic and other materials, U.S. Geological Survey: U.S. Geological Survey Open-File Report 02-223, 7 p., accessed June 7, 2010, at http://pubs.usgs.gov/of/2002/ofr-02-0223/L06AS24Se_M.pdf.

Kilburn, J.E., Smith, D.B., Closs, L.G., and Smith, S.M., 2007, Major- and trace-element concentrations in soils from two geochemical surveys (1972 and 2005) of the Denver, Colorado, metropolitan area: U.S. Geological Survey Data Series 299, 5 p., accessed June 7, 2010 at http://pubs.usgs.gov/ds/299/downloads/pdf/DS299.pdf.

National Institute of Standards and Technology, 2003, Certificate of analysis - Standard Reference Material ${ }^{\circledR} 2709$, San Joaquin soil baseline trace element concentrations: Gaithersberg, Md., National Institute of Standards and Technology, 12 p., accessed June 7, 2010, at https://www-s.nist.gov/srmors/certificates/archive/2709\%20January\%2018,\%202002.pdf.

Natural Resources Conservation Service, 2008, Sharpsburg series: National Cooperative Soil Survey, unpaged, accessed June 7, 2010, at http://www2.ftw.nrcs.usda.gov/osd/dat/S/SHARPSBURG.html.

Severson, R.C., and Tourtelot, H.A., 1994, Assessment of geochemical variability and a listing of geochemical data for surface soils of the Front Range Urban Corridor, Colorado: U.S. Geological Survey Open-File Report 94-648, 120 p.

Smith, D.B., Woodruff, L.G., O’Leary, R.M., Cannon, W.F., Garrett, R.G., Kilburn, J.E., and Goldhaber, M.B., 2009, Pilot studies for the North American Soil Geochemical 
Landscapes Project — Site selection, sampling protocols, analytical methods, and quality control protocols: Applied Geochemistry, v. 24, no. 8, p. 1357-1368.

Taylor, J.K., 1987, Quality assurance of chemical measurements: Chelsea, Mich., Lewis Publishers, $352 \mathrm{p}$.

Tidball, R.R., 1984, Geochemical survey of Missouri-Geography of soil geochemistry of Missouri agricultural soils: U.S. Geological Survey Professional Paper 954-H, 54 p.

U.S. Environmental Protection Agency, 2007, Method 7471B (revision 2)-Mercury in solid or semisolid waste (manual cold-vapor technique), chap. 3 of Inorganic analytes, Test methods for evaluating solid wastes: U.S. Environmental Protection Agency SW846, accessed June 7, 2010, at

http://www.epa.gov/epawaste/hazard/testmethods/sw846/pdfs/7471b.pdf. 